\title{
Cushing's Syndrome in Pregnancy: An Overview
}

\begin{abstract}
Cushing's syndrome (CS) during pregnancy is a rare condition with fewer than 150 cases reported in the literature. Adrenal adenomas were found to be the commonest cause, followed by Cushing's disease. The gestation dramatically affects the maternal hypothalamic-pituitary-adrenal axis, resulting in increased hepatic production of corticosteroid-binding globulin (CBG), increased levels of serum, salivary and urinary free cortisol, lack of suppression of cortisol levels after dexamethasone administration and placental production of $\mathrm{CRH}$ and ACTH. Moreover, a blunted response of ACTH and cortisol to exogenous $\mathrm{CRH}$ may also occur. Therefore, the diagnosis of CS during pregnancy is much more difficult. Misdiagnosis of CS is also common, as the syndrome may be easily confused with preeclampsia or gestational diabetes. Because CS during pregnancy is usually associated with severe maternal and fetal complications, its early diagnosis and treatment are critical. Surgery is the treatment of choice for CS in pregnancy, except perhaps in the late third trimester, with medical therapy being a second choice. There does not seem to be a rationale for supportive treatment alone. (Arq Bras Endocrinol Metab 2007;51/8:1293-1302)
\end{abstract}

Keywords: Cushing's syndrome; Cushing's disease; Adrenal adenoma; Pregnancy

\section{RESUMO}

Síndrome de Cushing na Gravidez: Uma Visão Geral.

A ocorrência de síndrome de Cushing (SC) durante a gravidez é rara, com menos de 150 casos reportados na literatura. Os adenomas adrenais parecem ser a causa mais comum seguidos da doença de Cushing. A gestação afeta de maneira dramática o eixo hipotálamo-hipófise-adrenal materno resultando em aumento da produção hepática da globulina ligadora de corticosteróides (CBG), aumento dos níveis séricos, salivares e livres urinários de cortisol, falta de supressão do cortisol após administração de dexametasona e produção placentária de CRH e ACTH. Além disso, pode também ocorrer bloqueio da resposta do ACTH e do cortisol ao $\mathrm{CRH}$ exógeno. Assim, o diagnóstico de $\mathrm{SC}$ durante a gravidez torna-se muito mais difícil. A falha em diagnosticar SC é também comum, já que a síndrome pode ser facilmente confundida com pré-eclampsia ou diabetes gestacional. Uma vez que a SC de ocorrência na gravidez é usualmente associada com graves complicações materno-fetais, seu diagnóstico e tratamento precoces tornam-se críticos. A cirurgia é o tratamento de escolha para a SC na gravidez, exceto, talvez, no final do $3^{\circ}$ trimestre, sendo o tratamento medicamentoso a segunda escolha. Não parece haver nenhum arrazoado para o tratamento de suporte isoladamente. (Arq Bras Endocrinol Metab 2007;51/8:1293-1302)

Descritores: Síndrome de Cushing; Doença de Cushing; Adenoma adrenal; Gravidez

\section{revisão}

\author{
LUCIO VILAR \\ MARIA DA CONCEIÇÃo FreITAS \\ LÚCIA Helena C. LIMA \\ RUY LYRA \\ Claudio E. Kater
}

\begin{abstract}
Division of Endocrinology and Metabolism, Hospital das Clínicas, Federal University of Pernambuco (LV), Division of Endocrinology and Metabolism, Hospital Getúlio Vargas (MCF, LHCL) Pernambuco University Medical School (RL), Recife, Brazil; and Division of Endocrinology and Metabolism, Department of Medicine, Federal University of São Paulo UNIFESP/EPM (CEK), São Paulo, Brazil.
\end{abstract}

Recebido em 05/10/07

Revisado em 12/10/07

Aceito em 15/10/07 
$\mathrm{P}$ REGNANCY IS UNCOMMON IN WOMEN with Cushing's syndrome (CS), with fewer than 150 cases reported in the world literature, as hyperandrogenism and hypercortisolism suppress pituitary secretion of gonadotropins $(1,2)$. However, because CS results in increased fetal and maternal complications, its early diagnosis and treatment are critical.

The hypothalamic-pituitary-adrenal (HPA) axis exerts profound, mostly inhibitory effects, on the reproductive axis, with corticotropin-releasing hormone $(\mathrm{CRH})$ and $\mathrm{CRH}$-induced proopio-melanocortin peptides inhibiting hypothalamic GnRH secretion, and glucocorticoids inhibiting pituitary $\mathrm{LH}$ and ovarian estrogen and progesterone secretion and rendering estrogen-target tissues, such as the endometrium, resistant to gonadal steroids $(4,5)$. These effects at the HPA axis are responsible for the "hypothalamic" amenorrhea of stress, depression and eating disorders, and the hypogonadism of CS (6,7). Moreover, CRH, the principal regulator of the HPA axis, has been identified in most female reproductive tissues including the uterus, the placenta, and the ovary. Placental CRH may participate in the physiology of pregnancy, in late pregnancy complications such as preterm labor and preeclampsia, and also in the onset of parturition. Increased levels of unbound placental CRH may be responsible for the hypercortisolism of the second half of pregnancy. This hypercortisolism is followed by a transient suppression of hypothalamic CRH secretion in the postpartum period. This may explain the depressive states frequently observed in the postpartum period (4-7).

The clinical diagnosis of CS during pregnancy may be missed because of the overlapping features of weight gain, hypertension, fatigue, hyperglycemia, and emotional changes that occur in normal pregnancy. The biochemical diagnosis is difficult to establish due to the normal hypercortisolism of pregnancy $(2,8)$. Indeed, pregnancy is associated with a state of increased HPA axis activity as shown by elevations in urinary free cortisol (UFC), total and free plasma cortisol, and corticosteroid-binding globulin (CBG) values (8). Also, during late pregnancy the adrenal glands have increased responsiveness to ACTH compared with non-pregnant women $(8)$.

\section{HORMONAL CHANGES IN HPA AXIS DURING PREGNANCY}

Gestation dramatically affects the maternal HPA axis. Increasing placental secretion of estrogen stimulates the production of CBG by the liver, thus stimulating cortisol production and increasing circulating levels of bound cortisol (8). However, both circulating and UFC levels also increase steadily during gestation, reaching values similar to those found in CS $(3,8)$. Indeed, total and free plasma cortisol concentrations rise in parallel across gestation, with plasma cortisol reported to be 2 - to 3 -fold higher in comparison with non-pregnant controls $(2,8-10)$. The increase in plasma cortisol occurs as early as the $11^{\text {th }}$ week of gestation (9), reaching a peak between the first and second trimesters, and a plateau in the third trimester (11). The hepatic production of CBG remains elevated until at least the $12^{\text {th }}$ postpartum day (8). Salivary cortisol, another measure of plasma free cortisol, is more than 2 -fold increased compared with non-pregnant controls in the third trimester $(8,12)$. The circadian rhythm of cortisol is preserved but may be partly blunted $(8,12)$.

UFC excretion parallels the rise in serum cortisol through the course of gestation $(2,8)$. Mean 24-h UFC is elevated at least $180 \%$ during gestation compared with non-pregnant levels (13). Among 15 normal pregnant women, the mean UFC excretion rate in the third trimester ranged from 188 to 696 $\mathrm{nmol} /$ day or $68 \mu \mathrm{g} /$ day (mean, $350 \mathrm{nmol} /$ day or $127 \mu \mathrm{g} /$ day) (14).

It was also demonstrated in late pregnancy and early post-partum that dexamethasone does not suppress plasma and urinary cortisol to the same degree as in the non-pregnant state $(2,15)$. Odagiri et al. (10) demonstrated a $40 \%$ vs. $87 \%$ suppression of plasma cortisol and similar effects on UFC after $1 \mathrm{mg}$ dexamethasone in normal second- to third-trimester pregnancy compared with controls. Advancing gestation is associated with increasing lack of suppression after 1 mg dexamethasone (10). This phenomenon has been attributed to CBG effects on cortisol, tissue refractoriness to glucocorticoids, and resetting of the maternal HPA feedback mechanism $(8,10)$. Others suggest that the anti-glucocorticoid effects of progesterone might contribute to tissue resistance $(8,10)$.

It should also be noted that the fetus is protected in early gestation from the effects of maternal hypercortisolism by placental $11 \beta$-hydroxysteroid dehydrogenase 2 (11 $\beta$-HSD2), which converts active glucocorticoids - cortisol and corticosterone - to their inactive 11 -keto-metabolites $(8,16)$.

Plasma ACTH levels rise throughout pregnancy, reaching a peak during labor and delivery (8). In one study, levels increased almost 3 -fold from the end of the first to the third trimester $(23-59 \mathrm{pg} / \mathrm{mL}$, measured by RIA; 5-13 pmol/liter) (17). Compared to healthy non-pregnant women, basal plasma ACTH 
levels in pregnancy have been varyingly reported as low $(17,18)$ or high $(19)$. Placentally derived ACTH may be a significant contributor to hypercortisolism in pregnancy (8).

The cause of ACTH increase during pregnancy is not clear, but may include placental synthesis and release of biologically active $\mathrm{CRH}$ and ACTH, pituitary desensitization to cortisol feedback, or enhanced pituitary responses to corticotropin-releasing factors such as vasopressin and CRH $(3,8)$.

Placental CRH, isolated in 1988 by Sasaki et al. (20), is identical to hypothalamic CRH in structure, immunoreactivity, bioactivity, and transcriptional sites (4). Plasma CRH levels rise exponentially by 1,000 fold as gestation progresses (4), beginning around 8wk gestation $(21,22)$. At the $35^{\text {th }}$ week there is a sharp increase to a peak of $4,000 \mathrm{pg} / \mathrm{mL}$ at 40 -week gestation $(23,24)$, with normalization to non-pregnant values within 24 h of delivery $(8,25,26)$.

Blunted response of ACTH and cortisol to exogenous $\mathrm{CRH}$ may also occur. In the series by Schulte et al. (27), intravenous administration of human $\mathrm{CRH}(\mathrm{l} \mu \mathrm{g} / \mathrm{kg})$ failed to increase plasma cortisol or ACTH in seven pregnant women one week before their expected delivery date. In contrast, a prompt ACTH response to $\mathrm{CRH}$ was observed when the same women were studied at $4-5$ week postpartum. Other investigators using a higher dose $(2 \mu \mathrm{g} / \mathrm{kg})$ during third trimester pregnancies demonstrated similar ACTH and cortisol increments to those of non-pregnant women (28). These observations are consistent with the hypothesis that impaired CRH response may be due to high endogenous cortisol concentrations with desensitization of the pituitary corticotrophs $(8,27)$.

\section{The HPA axis during parturition and post-partum period}

Plasma CRH, ACTH, and cortisol concentrations increase several-fold with the onset of labor and delivery $(8,17,29,30)$. Peak CRH levels are found within $48 \mathrm{~h}$ before delivery and fall during labor, consistent with a preeminent role for $\mathrm{CRH}$ in parturition $(8,31)$.

In the immediate post-partum period, plasma $\mathrm{CRH}, \mathrm{ACTH}$, and cortisol levels decrease rapidly toward the non-pregnant range, consistent with their biological half-lives (8). Both CRH and ACTH normalize within $2 \mathrm{~h}$ from delivery whereas normalization of plasma cortisol levels is more protracted $(8,32)$. In one series, mean post-partum 24 -h plasma cortisol levels were $5.4 \mu \mathrm{g} / \mathrm{dL}$ (149 nmol/liter), whereas these values in the second and third trimesters were 18.8 $\mu \mathrm{g} / \mathrm{dL}(518 \mathrm{nmol} / \mathrm{liter})$ and $20.3 \mu \mathrm{g} / \mathrm{dL}$ (560 nmol/liter), respectively (13).

Lack of normal cortisol suppression after $1 \mathrm{mg}$ of dexamethasone is quite common in the immediate postpartum and was found in $82 \%$ of women evaluated by Greenwood and Parker (33). This abnormality may persist until the $5^{\text {th }}$ postpartum week (34).

\section{CUSHING'S SYNDROME DURING PREGNANCY}

\section{Frequency}

CS is rarely associated with pregnancy, probably because hypercortisolism prevents normal follicular development and ovulation $(2,8)$. The first description of CS occurring in pregnancy was reported by Hunt and McConahey, in 1953 (35). Since then, at least 140 pregnancies have been reported in 126 subjects as individual cases and small case series $(1,3,8,36,37)$. Multiple pregnancies occurred in about $10 \%$ of the patients $(8,9,39)$. The mean gestational age at diagnosis is approximately 18 weeks $(3,8)$.

\section{Etiology}

The etiology of CS differs between the pregnant and non-pregnant state. Indeed, adrenal adenomas underlie a disproportionately high proportion of CS cases, accounting for approximately $40-50 \%$ of cases in pregnancy $(8,39-41)$, in comparison with $17-29 \%$ in nonpregnant women (42-44). Conversely, Cushing's disease appears to be less common in pregnancy, with rates of $63-72 \%$ in the general population $(42-44)$, compared with $33 \%$ in 122 pregnant women $(8,39,41,45)$. Ectopic ACTH secretion has been reported to cause CS in four patients, two of whom had a diagnosis of pheochromocytoma $(46,47)$. Pheochromocytoma also was associated with one case of apparent ACTH-independent hypercortisolism in pregnancy (48). The increased incidence of adrenal CS in pregnancy is not understood (8). It is possible that women with Cushing's disease are less ovulatory than those with primary adrenal disease, perhaps because they are more hyperandrogenic $(8,49)$. Another likely explanation is that unrecognized illicit $\mathrm{LH} / \mathrm{hCG}$ receptor expression was considered to be adrenal adenoma (50,51). Most patients with ectopic ACTH secretion have severe hypercortisolism and amenorrhea, which probably accounts for the reduced prevalence of this condition in pregnancy $(8,46,47)$.

There have been a few reports of recurrent CS during pregnancy that spontaneously remitted after 
delivery $(15,38,52)$. CS induced by pregnancy seems to be caused by a product(s) of the feto-placental unit. Such a compound may act either by l) stimulation of the maternal pituitary to produce ACTH, which, in turn, stimulates the adrenals; 2) direct stimulation of the maternal adrenal glands; or 3 ) activation of an ectopic source of either an adrenal or pituitary stimulator. Direct stimulation of the maternal adrenals may be the result of either an abnormally high level of an adrenal-stimulating product of the feto-placental unit or unusual responsiveness of the adrenals to normal pregnancy levels of an adrenal stimulator. Several placental peptides could be considered as candidate stimulators such as placental CRF, placental ACTH, or an as yet undefined compound (15).

\section{Maternal and fetal morbidity and mortality}

CS is associated with significant maternal morbidity and mortality in approximately $70 \%$ of cases. The most common complications in pregnancy are hypertension and diabetes or impaired glucose tolerance $(8,40,48,53)$. In smaller numbers of cases, pregnancies were associated with poor wound healing, osteoporosis, fracture, severe psychiatric complications, maternal cardiac failure, and death $(8,54-56)$ (table 1$)$. Maternal death is rare and one death was reported in the month after delivery as a result of cerebrovascular disease and disseminated intravascular coagulation caused by pheochromocytoma (47). Another woman died due to complications from adrenalectomy and cesarean-section (57).

In a review of 65 pregnancies in patients with CS Buescher et al. (40) found hypertension in twothirds of the pregnancies, glucose intolerance in onethird, and preeclampsia in approximately $10 \%$; moreover, three maternal deaths were reported. Maternal morbidity was apparently more severe in patients with adrenal neoplasms than in those with pituitary disease. Maternal outcomes, however, can be improved by reversal of the hypercortisolism (39).

Fetal complications include early spontaneous abortions, the rate of which may be underestimated because of delay in the diagnosis of CS $(8,37,39)$. Premature labor (20 to 38 weeks of gestation) is common and has been reported in up to $60 \%$ of pregnancies $(3,8)$. Consequently, a pregnancy complicated by CS is a high-risk obstetric condition. Fetal mortality and morbidity are primarily related to prematurity. Intrauterine growth retardation is also common. In the series of 65 pregnancies in patients with CS (40), perinatal death was reported in $15.4 \%$, and stillbirth accounted for half the cases. In that same series, intrauterine growth restriction was seen in $26.2 \%$ (40). In a comparison of the fetal outcomes in CS, Pickard et al. (4l) observed more pregnancies reaching term with less prematurity, a lower abortion rate, and fewer cases of stillbirth in patients with Cushing's disease than in those with CS due to adrenal adenoma or carcinoma. In a series of 136 pregnancies complicated by CS there were 107 (79\%) live births (3); 43\% of births were premature. There were eight stillbirths, six intrauterine deaths/spontaneous abortions, and one ectopic pregnancy. Six therapeutic abortions were undertaken, and in three cases the outcome was uncertain. One infant died from respiratory distress and hyaline membrane disease (58). Intraventricular hemorrhage caused another infant death (69). Viardot et al. (60) reported two cases of pregnancy in patients with CS, who developed a severe, sudden and early HELLP syndrome (hemolytic anemia, elevated liver enzymes and low platelet count), which eventually progressed to fetal death. Fetal adrenal insufficiency occurs rarely, and signs of glucocorticoid excess have not been

Table 1. Frequency of maternal and fetal complications arising in CS during pregnancy.

\begin{tabular}{ll}
\hline Maternal morbidity & Fetal morbidity \\
\hline Hypertension (68\%) & Prematurity (43\%) \\
\hline Diabetes or impaired glucose tolerance (25\%) & Stillbirths (6\%) \\
Preeclampsia (14\%) & $\begin{array}{l}\text { Spontaneous abortion/intrauterine death (5\%) } \\
\text { Infant death in two cases (acute hepatitis; } \\
\text { Osteoporosis and fracture (5\%) } \\
\text { sepsis and gastroenteritis) }\end{array}$ \\
Cardiac failure (3\%) & $\begin{array}{l}\text { Intrauterine growth retardation (21\%) } \\
\text { Pypoadrenalism (2\%) }\end{array}$ \\
Wound infection (2\%) & $\begin{array}{l}\text { Single reports of cleft lip, patent ductus and } \\
\text { coarctation }\end{array}$ \\
Maternal death (2\%) & $\begin{array}{l}\text { Intraventricular hemorrhage in two cases } \\
\text { postpartum }\end{array}$ \\
\hline
\end{tabular}

Adapted from Ref. 8 
reported, suggesting that placental degradation of cortisol protects the fetus $(8,58)$. Congenital malformations are also rare (8). For example, Fayol et al. (61) presented a case of transient hypertrophic obstructive cardiomyopathy in a newborn whose mother had hypercortisolism due to a primary adrenal lesion.

\section{Screening and diagnosis}

\section{Clinical features}

There are non-significant differences in the clinical features of pregnant and non-pregnant women with CS. In both situations weight gain, hypertension, bruising, and hirsutism are usually present. Unfortunately, CS is often not detected until 12-26 weeks of gestation, partially because changes in physical appearance are ascribed to pregnancy rather than CS $(8,40)$. On the other hand, some of the manifestations of CS may be attributed to complications of pregnancy (gestational diabetes, preeclampsia, etc.), thus contributing to delay in the diagnosis of CS (1-3).

\section{Screening tests}

In non-pregnant women, screening tests for CS aim at investigating an enhanced cortisol production or a deranged diurnal rhythm, or documenting blunted suppression of cortisol after dexamethasone suppression. The normal gestational changes in the HPA axis alter these parameters and complicate the screening process for CS $(8,10,18,28)$. As reviewed above, these changes include estrogen-dependent increases in $\mathrm{CBG}$, increases in plasma cortisol and ACTH, and a 2to 3 -fold increase in plasma free cortisol and UFC $(8,17,28)$. The three most useful tools for diagnosis of CS are the measurement of 24-h UFC levels, low-dose dexamethasone-suppression tests, and determination of midnight serum cortisol or late-night salivary cortisol (42,62-65). However, none of these tests are perfect, every one has different sensitivities and specificities and several are usually required to enable a better diagnostic accuracy (66).

There is no significant change when mean morning plasma cortisol levels are compared in pregnant women with CS and in normal pregnancy (17). Thus, as in the non-pregnant individual, morning plasma cortisol concentrations generally do not establish the diagnosis of CS during gestation (8).

The nocturnal nadir of plasma cortisol is lost in CS but is preserved in pregnancy, although with a higher absolute value $(8,17)$. Elevation of midnight or late-evening serum cortisol is found in virtually all non-pregnant women with CS. Similarly, elevation of midnight or late-evening salivary cortisol levels have sensitivity of 90-96\% and specificity of 96-100\% (6769). As already mentioned, an increase of salivary cortisol in the late evening may occur in late pregnancy $(12,67)$. There is only one case report that documents the potential utility of this noninvasive measure in pregnancy (70). An elevated midnight or evening plasma cortisol has also helped to confirm hypercortisolism in some pregnant women $(53,71)$. However, no studies have developed a diagnostic threshold for interpretation of the test in pregnant patients (8).

Measurement of urinary cortisol reflects a direct assessment of circulating free (biologically active) cortisol. It has been often considered the gold standard test for detection of hypercortisolism. Indeed, in some studies UFC measurement was shown to have a diagnostic sensitivity and specificity of $95-100 \%$ and $98 \%$, respectively, in the differentiation of CS from obesity (63-66). However, it was noted that $11 \%$ of patients had at least one of four 24$\mathrm{h}$ collections with values within the normal range (42). In non-pregnant women, UFC increases above 4-fold normal are virtually diagnostic of CS (66). During pregnancy, UFC excretion is normal in the first trimester but it increases up to three times the upper limit of normal during the second and third trimesters (13-15). In a recent review, a mean 8-fold increase (range, 2 - to 22 -fold) of UFC levels in pregnant CS patients was found (3). This overlap of UFC values in pregnant women with and without CS suggests that only UFC values in the second and third trimester greater than three times the upper limit of normal can be taken to indicate CS $(3,8)$.

Two low-dose dexamethasone-suppression tests (LD-DST) are in widespread use: the overnight and the $48 \mathrm{~h}$ test. In the former, $1 \mathrm{mg}$ of dexamethasone is given at 23:00 and the concentration of cortisol in serum measured the next day at 8:00-9:00. In the 48 $\mathrm{h}$ test, dexamethasone is given at the dose of $0.5 \mathrm{mg}$ every 6 h for 2 days at 9:00, 15:00, 21:00, and 3:00 with measurements of cortisol in serum at 9:00 at the start and end of the test $(42,63,64)$. To exclude CS the concentration of serum cortisol should be of $1.8 \mu \mathrm{g} / \mathrm{dL}(50 \mathrm{nmol} / \mathrm{L})$ or less after either test $(42,66,72)$. In some series, this cut-off value provided a sensitivity of $98-100 \%(44,72)$. However, in other series, some $3-8 \%$ of patients with Cushing's disease retained sensitivity to dexamethasone and showed suppression of serum cortisol to less than $1.8 \mu \mathrm{g} / \mathrm{dL}$ on either test $(73,74)$.

As commented earlier, suppression of both plasma and UFC by dexamethasone is blunted in 
pregnancy $(8,15)$. Therefore, the LD-DST has a more limited utility in pregnancy than in the general population because of an increased risk for false-positive results (8). Nevertheless, pregnancy does not impair the sensitivity of these tests. Among 17 pregnant women with CS plasma cortisol levels following LDDST ranged from 5.5 to $54.3 \mu \mathrm{g} / \mathrm{dL}$ (152 to 1,499 nmol/liter) (3).

In summary, we recommend a combination of UFC assessment and measurement of midnight salivary cortisol for screening of CS in pregnancy.

\section{Tests for the differential diagnosis}

The main tools for the differential diagnosis are the determination of plasma ACTH levels, non-invasive dynamic tests (CRH or desmopressin stimulation tests and high-dose DST, HD-DST), bilateral inferior petrosal sinus sampling, and imaging studies $(42,63-66)$. The measurement of plasma ACTH is the first step to be performed in order to determine the etiology of CS (42). Hypercortisolism, regardless of the cause, inhibits ACTH secretion by normal corticotrophs. In non-pregnant women with CS, ACTH levels are typically reduced $(<10 \mathrm{pg} / \mathrm{mL})$ in patients with autonomous adrenal disorders and inappropriately normal or increased in those with tumoral ACTH production (Cushing's disease or EAS) (42-44).

Eight of 16 patients (50\%) with CS caused by adrenal adenomas or ACTH-independent adrenal hyperplasia had values greater than $10 \mathrm{pg} / \mathrm{mL}(3)$. Therefore, pregnant patients with adrenal causes of CS do not consistently have suppressed plasma ACTH values, probably reflecting effects of placental CRH that is not suppressed by hypercortisolism (8). As a result, the recommended diagnostic ACTH thresholds for adrenal CS in the general population are not valid in pregnancy and may lead to misdiagnosis $(8,62)$.

The rational of the HD-DST relies on the fact that, in most situations, the tumoral corticotroph cells in Cushing's disease retain some responsiveness to the negative feedback effects of glucocorticoids whereas tumors ectopically secreting ACTH and autonomous adrenal diseases do not (42). The standard or classic test consists in the determination of serum cortisol or UFC after the administration of oral dexamethasone at a dose of $2 \mathrm{mg}$ every $6 \mathrm{~h}$ for $48 \mathrm{~h}$. As the $48 \mathrm{~h} \mathrm{HD-}$ DST is somewhat cumbersome, a preferable alternative is the 8 -mg overnight DST which involves the administration of a single 8 - $\mathrm{mg}$ dose of dexamethasone orally at 23:00 with measurement of serum cortisol at 8:00 before and after administration $(42,63)$. Classically, a cortisol suppression greater than $50 \%$ is indicative of Cushing's disease. This cut-off value provides a sensitivity of $60-100 \%$ and specificity of $65-100 \%$ in the standard test while the corresponding figures in the overnight test are $60-100 \%$ and $59-92 \%$, respectively $(42,75)$. In our series, serum cortisol suppression $>50 \%$ following HD-DST was observed in $78 \%$ of patients with Cushing's disease, in one third of patients with EAS and in none of those with an autonomous adrenal disease (44). However, cortisol suppression $>80 \%$ only occurred in patients with Cushing's disease. In the Italian multicenter study (43), cortisol suppression $>80 \%$ also had $100 \%$ specificity. A similar response may rarely be found in patients with EAS $(65,76)$.

Some authors have advocated abandoning HDDST due to its limited diagnostic accuracy $(76,77)$. We believe that this test may be useful when analyzed together with other non-invasive dynamic tests $(\mathrm{CRH}$ ou desmopressin test) or when cortisol suppression is $>80 \%$. Moreover, in pregnant patients, the test may help discriminate adrenal forms of CS from Cushing's disease, which may be useful given the difficulties in interpretation of plasma ACTH and the increased prevalence of adrenal disorders in pregnancy (8). In a recent systematic review, no patient with a primary adrenal cause of CS showed suppression, whereas four of seven patients (57\%) with Cushing's disease did (3).

The basis of the CRH stimulation test is the fact that pituitary tumor corticotrophs remain responsive to $\mathrm{CRH}$ stimulation, whereas adrenal tumors and most ectopic ACTH-secreting tumors do not respond $(42,65,66)$. The test involves basal sampling for cortisol and ACTH followed by intravenous administration of $1 \mu \mathrm{g} / \mathrm{kg}$ or, more usually, $100 \mu \mathrm{g}$ of CRH. The largest individual series set criteria for Cushing's disease of 35\% increase in ACTH and 20\% increase in cortisol following $\mathrm{CRH}$ administration (78). In that study, the CRH test had a sensitivity and specificity of $91 \%$ and $88 \%$, respectively, using cortisol criteria, whereas the corresponding figures for ACTH criteria were $93 \%$ and $100 \%$, respectively (78).

Ovine $\mathrm{CRH}$ is a Food and Drug Administration (FDA) category $\mathrm{C}$ drug, recommended for use in pregnancy only when absolutely clinically indicated. In animal studies no teratogenic or adverse behavioral effects were found after $100 \mu \mathrm{g}$ human CRH during organogenesis (79). It was also shown that plasma ACTH responses to human CRH $(1 \mu \mathrm{g} / \mathrm{kg}$ ) were reduced in the third-trimester of normal pregnancies (29). Although the CRH stimulation test has not been systematically studied in CS in pregnancy, in the literature reports there was a substantial rise in plasma cor- 
tisol (44-130\%), consistent with surgically confirmed Cushing's disease, and no adverse effects were observed $(8,55,71,80)$.

An alternative to $\mathrm{CRH}$ stimulation test is the desmopressin stimulation test that involves the intravenous administration of $10 \mu \mathrm{g}$ of desmopressin $(43,44)$. In this test the cortisol responses have a sensitivity of $84 \%$ and specificity of $83 \%$, while ACTH responses provide poorer discrimination with a sensitivity of $77 \%$ and specificity of $73 \%$ (42). Therefore, testing with desmopressin is inferior to testing with $\mathrm{CRH}$ in terms of sensitivity and specificity, but this peptide is cheaper and more easily available worldwide. We could not find any reports on the use of desmopressin test during pregnancy. Nevertheless, therapy with desmopressin was shown to be safe for mother and child in the treatment of gestational diabetes insipidus (81).

Concerning imaging studies, computed tomography scans is contraindicated during pregnancy due to the risk of ionizing radiation (71). Therefore, an adrenal evaluation by magnetic resonance imaging (MRI) is indicated in patients with suppressed or low-normal ACTH levels. Pituitary MRI should be performed in all patients with apparent ACTH-dependent CS, whereas chest and abdominal MRI should be considered for those with suspected EAS. A recent consensus statement concluded that pituitary MRI may provide a definitive diagnosis in the setting of responses to $\mathrm{CRH}$ and dexamethasone consistent with Cushing's disease when a greater than 6- $\mathrm{mm}$ pituitary adenoma is identified (62). However, because of potential (but unproven) teratogenic effects of MRI in the first trimester during organogenesis, it is considered contraindicated at that time, but is considered safe after the $32^{\text {nd }}$ week of gestation. Between 12 and 32 weeks, the potential and largely unknown risks of MRI must be balanced with the potential benefits (8). Moreover, the use of the contrast agent gadolinium should be avoided in pregnancy, because it is FDA category C (8). In one series of non-pregnant individuals, the sensitivity of MRI for detection of Cushing's disease decreased from 52\% with contrast to $38 \%$ without it (83). It should also be noted that pituitary MRI will detect an incidental tumor $(\leq 6 \mathrm{~mm})$ in up to $10 \%$ of healthy individuals (84). Furthermore, as the normal pituitary increases in size up to 2 -fold by the third trimester, there may be an increased number of incidentalomas identified in pregnancy using these criteria (8).

For pregnant women with $\mathrm{CRH}$ and DST responses consistent with Cushing's disease, and pitu- itary lesions larger than $6 \mathrm{~mm}$, usually no additional testing is necessary (8), just as in the non-pregnant population (62). For others, an invasive procedure such as bilateral inferior petrosal sinus sampling (BIPSS) may be required. The test involves catheterization of the petrosal sinuses draining the pituitary gland and simultaneous sampling from these and a peripheral vein for ACTH measurement before and after administration of CRH. A central-to-peripheral ACTH gradient greater than 2 (basal) or 3 (after administration of CRH or desmopressin) is consistent with the diagnosis of Cushing's disease (sensitivity and specificity of 94\%) (82). The perceived risk of ionizing radiation probably has limited its use in pregnancy, and we could only find three cases in literature where BIPPS was performed $(3,80)$. Specific precautions, including a direct jugular approach for catheter insertion and use of additional lead barrier protection, are necessary during pregnancy. It has been advocated that BIPSS should only be considered during pregnancy after completion of careful noninvasive assessment and only in centers with special expertise using the technique. Also, because it is not known whether pregnant patients with adrenal disease have complete pituitary suppression, the usual criteria for interpretation may not exclude these patients $(3,8)$.

In summary, in patients with confirmed CS, a low plasma ACTH level should prompt imaging of the adrenals. However, in cases with borderline or elevated ACTH, a combination of the 8-mg DST and CRH (or desmopressin) stimulation testing is suggested to establish the presence of, and distinguish between, the ACTH-dependent forms. BIPSS may be necessary in patients with discordant biochemical or imaging findings $(8)$.

\section{Treatment}

As already mentioned, untreated CS is associated with significant maternal morbidity, including diabetes, hypertension, heart failure, and preeclampsia, and adverse fetal outcomes, such as premature births, spontaneous abortions, stillbirth, perinatal death, and intrauterine growth retardation $(1,8,15,40,41)$. It is assumed that these outcomes could be prevented by reducing UFC excretion to the upper part of the range observed in normal pregnancy $(8,14,85)$. However, treatment for pregnant patients with CS has been implemented only sporadically, generally late in the course of the pregnancy. As a result, the ability of treatment to prevent adverse outcomes is not well established. The treatment outcomes of 136 pregnant women with CS were recently reviewed (3). When no 
active treatment was given, there were 59 live births (76\%) compared with 50 live births (89\%) in women in whom treatment was instituted at a mean gestational age of $20 \pm 1$ weeks (3). In a patient with apparent post-surgical remission, the progression to eclampsia and premature delivery occurred, suggesting that a successful treatment does not necessarily prevent adverse outcomes (3).

Adrenalectomy for patients with adrenal tumors seems to be beneficial and the birth rate after surgery is approximately $87 \%(8,34,39,86)$. Among 40 women with Cushing's disease, approximately 20\% underwent transsphenoidal surgery (53), whereas the remainder was given medical therapy and/or was submitted to adrenalectomy; one case of unrecognized pregnancy had external pituitary irradiation $(3,8,39)$. A high proportion, either presenting late in pregnancy or before modern management, was left untreated $(3,8,36,87)$.

Concerning medical therapy, metyrapone has been used most often and has had no adverse effects on maternal hepatic function or fetal development in the small number of cases reported to date $(8,59,88)$. However, there is one report of fetal hypoadrenalism after metyrapone (15). Moreover, this drug may exacerbate hypertension and favor progression to preeclampsia, which may limit its use $(8,79,88)$. Ketoconazole has been used successfully in three pregnancies without adverse events (89-91), including a patient who had discontinued contraception while using ketoconazole (600-1,000 mg/day) for Cushing's disease (89). Despite known antiandrogenic effects of ketoconazole through inhibition of aromatase activity, a normal male infant was delivered at the $37^{\text {th }}$ week $(89)$. It should be borne in mind that ketoconazole crosses the placenta and is teratogenic and abortifacient in the rat, so that the drug is FDA category C (3). Cyproheptadine is not recommended due to lack of efficacy (92). Aminoglutethimide and mitotane are contraindicated $(3,8)$; the former can induce fetal masculinization (93) whereas the latter has teratogenic effects (94).

In summary, surgery is the treatment of choice for CS in pregnancy, except perhaps late in the third trimester, with medical treatment being a second choice. There does not seem to be a rationale for supportive treatment alone $(3,8)$.

\section{REFERENCES}

1. Kita M, Sakalidou M, Saratzis A, loannis S, Avramides A Cushing's syndrome in pregnancy: Report of a case and review of the literature. Hormones 2007;6:242-6.
2. Sheeler LR. Cushing's syndrome and pregnancy. Endocrinol Metab Clin North Am 1994;23:619-27.

3. Lindsay JR, Jonklaas J, Oldfield EH, Nieman LK. Cushing's syndrome during pregnancy: Personal experience and review of the literature. J Clin Endocrinol Metab 2005;90:3077-83.

4. Magiakou MA, Mastorakos G, Webster E, Chrousos GP. The hypothalamic-pituitary-adrenal axis and the female reproductive system. Ann NY Acad Sci 1997;816:42-56.

5. Mastorakos G, Pavlatou MG, Mizamtsidi M. The hypothalamicpituitary-adrenal and the hypothalamic-pituitary-gonadal axes interplay. Pediatr Endocrinol Rev 2006;(suppl 1):172-81.

6. Vitoratos N, Papatheodorou DC, Kalantaridou SN, Mastorakos G. "Reproductive" corticotropin-releasing hormone. Ann NY Acad Sci 2006;1092:310-8.

7. Kalantaridou S, Makrigiannakis A, Zoumakis E, Chrousos GP. Peripheral corticotropin-releasing hormone is produced in the immune and reproductive systems: actions, potential roles and clinical implications. Front Biosci 2007;12:572-80.

8. Lindsay JR, Nieman LK. The hypothalamic-pituitary-adrenal axis in pregnancy: Challenges in disease detection and treatment. Endocr Rev 2005;26:775-99.

9. Demey-Ponsart E, Foidart JM, Sulon J, Sodoyez JC. Serum CBG, free and total cortisol and circadian patterns of adrenal function in normal pregnancy. J Steroid Biochem 1982; 16:165-9.

10. Odagiri E, Ishiwatari N, Abe $\mathrm{Y}$, Jibiki K, Adachi T, Demura H, et al. Hypercortisolism and the resistance to dexamethasone suppression during gestation. Endocrinol Jpn 1988;35:685-90.

11. Nolten WE, Rueckert PA. Elevated free cortisol index in pregnancy: possible regulatory mechanisms. Am J Obstet Gynecol 1981;139:492-8.

12. Scott EM, McGarrigle HH, Lachelin GC. The increase in plasma and saliva cortisol levels in pregnancy is not due to the increase in corticosteroid-binding globulin levels. J Clin Endocrinol Metab 1990;71:639-44.

13. Cousins $L$, Rigg L, Hollingsworth $D$, Meis $P$, Halberg F, Brink $\mathrm{G}$, et al. Qualitative and quantitative assessment of the circadian rhythm of cortisol in pregnancy. Am J Obstet Gynecol 1983; $145: 411-6$

14. Lindholm J, Schultz-Moller N. Plasma and urinary cortisol in pregnancy and during estrogen-gestagen treatment. Stand J Clin Lab Invest 1972; 31:119-22.

15. Wallace C, Toth EL, Lewanczuk RZ, Siminoski K. Pregnancyinduced Cushing's syndrome in multiple pregnancies. J Clin Endocrinol Metab 1996;81:15-21.

16. Seckl JR, Cleasby M, Nyirenda MJ. Glucocorticoids, 11 $\beta$ hydroxysteroid dehydrogenase, and fetal programming. Kidney Int 2000;57:1412-7.

17. Carr B, Parker Jr CR, Madden JD, MacDonald PC, Porter JC. Maternal plasma adrenocorticotrophin and cortisol relationships throughout human pregnancy. Am J Obstet Gynecol 1981;139:416-22.

18. Mukherjee K, Swyer GI. Plasma cortisol and adrenocorticotrophic hormone in normal men and non-pregnant women, normal pregnant women and women with pre-eclampsia. J Obstet Gynaecol Br Commonw 1972;79:504-12.

19. Genazzani AR, Petraglia F, Parrini D, Nasi A, Angioni G, Facchinetti $F$, et al. Lack of correlation between amniotic fluid and maternal plasma contents of $\beta$-endorphin, $\beta$-lipotropin, and adrenocorticotropic hormone in normal and pathologic pregnancies. Am J Obstet Gynecol 1984;148:198-203.

20. Sasaki A, Tempst P, Liotta AS, Margioris AN, Hood LE, Kent $\mathrm{SB}$, et al. Isolation and characterization of a corticotropinreleasing hormone-like peptide from human placenta. J Clin Endocrinol Metab 1988;67:768-73.

21. Magiakou MA, Mastorakos G, Webster E, Chrousos GP. The hypothalamic-pituitary-adrenal axis and the female reproductive system. Ann NY Acad Sci 1997;816:42-56.

22. Sorem KA, Smikle CB, Spencer DK, Yoder BA, Graveson MA, Siler-Khodr TM. Circulating maternal corticotropin-releasing hormone and gonadotropin-releasing hormone in normal and abnormal pregnancies. Am J Obstet Gynecol 1996; 175:912-6. 
23. Nolten WE, Lindheimer MD, Rueckert PA, Oparil S, Ehrlich EN. Diurnal patterns and regulation of cortisol secretion in pregnancy. J Clin Endocrinol Metab 1980;51:466-72.

24. Goland RS, Wardlaw SL, Blum M, Tropper PJ, Stark RI. Biologically active corticotropin-releasing hormone in maternal and fetal plasma during pregnancy. Am J Obstet Gynecol 1988;159:884-90.

25. Kalantaridou SN, Makrigiannakis A, Mastorakos G, Chrousos GP. Roles of reproductive corticotropin-releasing hormone. Ann NY Acad Sci 2003;997:129-35.

26. Mastorakos G, Ilias I. Maternal and fetal hypothalamic-pituitary-adrenal axes during pregnancy and postpartum. Ann NY Acad Sci 2003;997:136-49.

27. Schulte HM, Weisner D, Allolio B. The corticotrophin releasing hormone test in late pregnancy: lack of adrenocorticotrophin and cortisol response. Clin Endocrinol (Oxf) 1990;33:99-106.

28. Suda $T$, Iwashita $M$, Ushiyama $T$, Tozawa $F$, Sumitomo $T$, Nakagami $Y$, et al. Responses to corticotropin-releasing hormone and its bound and free forms in pregnant and nonpregnant women. J Clin Endocrinol Metab 1989;69:38-42.

29. Campbell EA, Linton EA, Wolfe CD, Scraggs PR, Jones MT, Lowry PJ. Plasma corticotropin-releasing hormone concentrations during pregnancy and parturition. J Clin Endocrinol Metab 1987;64:1054-9.

30. Sasaki A, Shinkawa O, Margioris AN, Liotta AS, Sato S, Murakami $O$, et al. Immunoreactive corticotropin-releasing hormone in human plasma during pregnancy, labor, and delivery. J Clin Endocrinol Metab 1987; 64:224-9.

31. Ochedalski T, Zylinska K, Laudanski T, Lachowicz A. Corticotrophin-releasing hormone and ACTH levels in maternal and fetal blood during spontaneous and oxytocin-induced labour. Eur J Endocrinol 2001;144:117-21.

32. Okamoto E, Takagi T, Makino T, Sata H, Iwata I, Nishino E, et al. Immunoreactive corticotropin-releasing hormone, adrenocorticotropin and cortisol in human plasma during pregnancy and delivery and postpartum. Horm Metab Res 1989;21:566-72.

33. Greenwood J, Parker G. The dexamethasone suppression test in the puerperium. Aust NZ J Psychiatry 1984;18:282-4.

34. Owens PC, Smith R, Brinsmead MW, Hall C, Rowley M, Hurt $\mathrm{D}$, et al. Postnatal disappearance of the pregnancy-associated reduced sensitivity of plasma cortisol to feedback inhibition. Life Sci 1987:41:1745-50.

35. Hunt $A B$, McConahey CW. Pregnancy associated with diseases of the adrenal glands. Am J Obstet Gynecol 1953; 66:970-87.

36. Chico A, Manzanares JM, Halperin I, Martinez de Osaba MJ, Adelantado J, Webb SM. Cushing's disease and pregnancy: report of six cases. Eur J Obstet Gynecol Reprod Biol 1996;64:143-6.

37. Yawar A, Zuberi LM, Haque N. Cushing's disease and pregnancy: Case report and literature review. Endocr Pract 2007; 13:296-9.

38. Hána V, Dokoupilová M, Marek J, Plavka R. Recurrent ACTHindependent Cushing's syndrome in multiple pregnancies and its treatment with metyrapone. Clin Endocrinol (Oxf) 2001:54:277-81.

39. Aron DC, Schnall AM, Sheeler LR. Cushing's syndrome and pregnancy. Am J Obstet Gynecol 1990;162:244-52.

40. Buescher MA, McClamrock HD, Adashi EY. Cushing's syndrome in pregnancy. Obstet Gynecol 1992;79:130-7.

41. Pickard J, Jochen AL, Sadur CN, Hofeldt FD. Cushing's syndrome in pregnancy. Obstet Gynecol Surv 1990; 45:87-93.

42. Newell-Price J, Trainer P, Besser GM, Grossman A. The diagnosis and differential diagnosis of Cushing's syndrome and pseudo-Cushing's states. Endocr Rev 1998;19:647-72.

43. Invitti C, Giraldi FP, de Martin M, Cavagnini F. Diagnosis and management of Cushing's syndrome: results of an Italian multicentre study. Study group of the Italian Society of Endocrinology on the pathophysiology of the hypothalamicpituitary-adrenal axis. J Clin Endocrinol Metab 1999; 84:440-8.
44. Vilar L, Naves LA, Freitas MC, Moura E, Canadas V, Leal E, et al. Endogenous Cushing's syndrome: Clinical and laboratorial features in 73 cases. Arq Bras Endocrinol Metab 2007; 51:566-74.

45. Casson IF, Davis JC, Jeffreys RV, Silas JH, Williams J, Belchetz PE. Successful management of Cushing's disease during pregnancy by transsphenoidal adenectomy. Clin Endocrinol (Oxf) 1987;27:423-8.

46. Guilhaume B, Sanson ML, Billaud L, Bertagna X, Laudat MH, Luton JP. Cushing's syndrome and pregnancy: Aetiologies and prognosis in twenty-two patients. Eur J Med 1992; 1:83-9.

47. Oh HC, Koh JM, Kim MS, Park JY, Shong YK, Lee KU, et al. A case of ACTH-producing pheochromocytoma associated with pregnancy. Endocr J 2003:50:739-44.

48. Finkenstedt G, Gasser RW, Hofle G, Lhotta K, Kolle D, Gschwendtner A, et al. Pheochromocytoma and sub-clinical Cushing's syndrome during pregnancy: Diagnosis, medical pre-treatment and cure by laparoscopic unilateral adrenalectomy. J Endocrinol Invest 1999;22:551-7.

49. Lado-Abeal J, Rodriguez-Arnao J, Newell-Price JD, Perry LA, Grossman $A B$, Besser GM, et al. Menstrual abnormalities in women with Cushing's disease are correlated with hypercortisolemia rather than raised circulating androgen levels. J Clin Endocrinol Metab 1998;83:3083-8.

50. Wy LA, Carlson HE, Kane P, Li X, Lei ZM, Rao CV. Pregnancyassociated Cushing's syndrome secondary to a luteinizing hormone/human chorionic gonadotropin receptor-positive adrenal carcinoma. Gynecol Endocrinol 2002;16:413-7.

51. Lacroix A, Hamet $P$, Boutin JM. Leuprolide acetate therapy in luteinizing hormone-dependent Cushing's syndrome. N Engl J Med 1999;341:1577-81.

52. Kriplani A, Buckshee K, Ammini AC. Cushing's syndrome complicating pregnancy. Aust NZ J Obstet Gynaecol 1993;33:428-30.

53. Mellor A, Harvey RD, Pobereskin LH, Sneyd JR. Cushing's disease treated by trans-sphenoidal selective adenomectomy in mid-pregnancy. Br J Anaesth 1998;80:850-2.

54. Tajika T, Shinozaki T, Watanabe H, Yangawa T, Takagishi K. Case report of a Cushing's syndrome patient with multiple pathologic fractures during pregnancy. J Orthop Sci 2002;7:498-500

55. Kamiya Y, Okada M, Yoneyama A, Jin-no Y, Hibino T, Watanabe $O$, et al. Surgical successful treatment of Cushing's syndrome in a pregnant patient complicated with severe cardiac involvement. Endocr J 1988;45:499-504.

56. Bevan JS, Gough MH, Gillmer MD, Burke CW. Cushing's syndrome in pregnancy: the timing of definitive treatment. Clin Endocrinol (Oxf) 1987;27:225-33.

57. Koerten JM, Morales WJ, Washington III SR, Castaldo TW. Cushing's syndrome in pregnancy: A case report and literature review. Am J Obstet Gynecol 1986;154:626-8.

58. Cabezon C, Bruno OD, Cohen M, Garcia S, Gutman RA. Twin pregnancy in a patient with Cushing's disease. Fertil Steril 1999;72:371-2.

59. Connell JM, Cordiner J, Davies DL, Fraser R, Frier BM, McPherson SG. Pregnancy complicated by Cushing's syndrome: Potential hazard of metyrapone therapy. Case report. Br J Obstet Gynaecol 1985;92:1192-5.

60. Viardot A, Huber P, Puder JJ, Zulewski H, Keller U, Muller B. Reproducibility of nighttime salivary cortisol and its use in the diagnosis of hypercortisolism compared with urinary free cortisol and overnight dexamethasone suppression test. J Clin Endocrinol Metab 2005;90:5730-6.

61. Fayol L, Masson P, Millet V, Simeoni U. Cushing's syndrome in pregnancy and neonatal hypertrophic obstructive cardiomyopathy. Acta Paediatr 2004;93:1400-2.

62. Arnaldi G, Angeli A, Atkinson AB, Bertagna $X$, Cavagnini $F$, Chrousos GP, et al. Diagnosis and complications of Cushing's syndrome: A consensus statement. J Clin Endocrinol Metab 2003;88:5593-602.

63. Kaye TB, Crapo L. The Cushing syndrome: An update on diagnostic tests. Ann Intern Med 1990;112:434-44. 
64. Meier CA, Biller BMK. Clinical and biochemical evaluation of Cushing's syndrome. Endocrinol Metab Clin North Am 1997;26:741-62.

65. Findling JW, Raff $H$. Diagnosis and differential diagnosis of Cushing's syndrome. Endocrinol Metab Clin North Am 2001;30:729-47.

66. Newell-Price J, Bertagna X, Grossman AB, Nieman LK. Cushing's syndrome. Lancet 2006;367:1605-17.

67. Yaneva M, Mosnier-Pudar H, Dugue MA, Grabar S, Fulla Y, Bertagna $X$. Midnight salivary cortisol for the initial diagnosis of Cushing's syndrome of various causes. J Clin Endocrinol Metab 2004:89:3345-51.

68. Raff H. Role of salivary cortisol determinations in the diagnosis of Cushing's syndrome. Curr Opin Endocrinol Diabetes 2004;11:271-5.

69. Castro M, Elias PC, Quidute AR, Halah FP, Moreira AC. Outpatient screening for Cushing's syndrome: The sensitivity of the combination of circadian rhythm and overnight dexamethasone suppression salivary cortisol tests. J Clin Endocrinol Metab 1999;84:878-82.

70. Billaud L, Sanson ML, Guilhaume B, Bertagna X, Abecassis JP, Luton JP. Cushing's syndrome during pregnancy. New diagnostic methods used in 3 cases of adrenal cortex carcinoma. Presse Med 1992;21:2041-5.

71. Doshi S, Bhat A, Lim KB. Cushing's syndrome in pregnancy. J Obstet Gynaecol 2003;23:568-9.

72. Wood PJ, Barth JH, Freedman DB, Perry L, Sheridan B. Evidence for the low dose dexamethasone suppression test to screen for Cushing's syndrome - Recommendations for a protocol for biochemistry laboratories. Ann Clin Biochem 1997;34:222-9.

73. Findling JW, Raff $\mathrm{H}$, Aron DC. The low-dose dexamethasone suppression test: A reevaluation in patients with Cushing's syndrome. J Clin Endocrinol Metab 2004;89:1222-6.

74. Isidori AM, Kaltsas GA, Mohammed S, Morris DG, Jenkins P, Chew SL, et al. Discriminatory value of the low-dose dexamethasone suppression test in establishing the diagnosis and differential diagnosis of Cushing's syndrome. J Clin Endocrinol Metab 2003;88:5299-306.

75. Bruno OD, Rossi MA, Contreras LN, Gomez RM, Galparsoro G, Cazado E, et al. Nocturnal high-dose dexamethasone suppression test in the aetiological diagnosis of Cushing's syndrome. Acta Endocrinol (Copenh) 1985;109:158-62.

76. Findling JW, Raff H. Cushing's syndrome: Important issues in diagnosis and management. J Clin Endocrinol Metab 2006;91:3746-53.

77. Aron DC, Raff H, Findling JW. Effectiveness versus efficacy: The limited value in clinical practice of high dose dexamethasone suppression testing in the differential diagnosis of ACTH-dependent Cushing's syndrome. J Clin Endocrinol Metab 1997;82:1780-5.

78. Nieman LK, Oldfield EH, Wesley R, Chrousos GP, Loriaux DL, Cutler GB Jr. A simplified morning ovine corticotropin-releasing hormone stimulation test for the differential diagnosis of adrenocorticotropin-dependent Cushing's syndrome. J Clin Endocrinol Metab 1993;77:1308-12.

79. Iwase TI, Ohyama N, Umeshita C, Inazawa K, Namiki M, Ikeda Y. Reproductive and developmental toxicity studies of hCRH [corticotrophin releasing hormone (human)] (II): study on intravenous administration of hCRH during the period of organogenesis in rats. Yakuri to Chiryo 1992;20(suppl 5):89-102.
80. Pinette MG, Pan YQ, Oppenheim D, Pinette SG, Blackstone J. Bilateral inferior petrosal sinus corticotropin sampling with corticotropin-releasing hormone stimulation in a pregnant patient with Cushing's syndrome. Am J Obstet Gynecol 1994;171:563-4.

81. Ray JG. DDAVP use during pregnancy: an analysis of its safety for mother and child. Obstet Gynecol Surv 1998; 53:450-5.

82. Lindsay JR, Nieman LK. Differential diagnosis and imaging in Cushing's syndrome. Endocrinol Metab Clin N Am 2005;34:403-21.

83. Tabarin A, Laurent F, Catargi B, Olivier-Puel F, Lescene $R$, Berge J, et al. Comparative evaluation of conventional and dynamic magnetic resonance imaging of the pituitary gland for the diagnosis of Cushing's disease. Clin Endocrinol (Oxf) 1998;49:293-300.

84. Vilar L, Azevedo MF, Barisic G, Naves LA. Pituitary incidentalomas. Arq Bras Endocrinol Metab 2005;49:651-6.

85. Trainer PJ. Corticosteroids and pregnancy. Semin Reprod Med 2002;20:375-80.

86. Pricolo VE, Monchik JM, Prinz RA, DeJong S, Chadwick DA, Lamberton RP. Management of Cushing's syndrome secondary to adrenal adenoma during pregnancy. Surgery 1990;108:1072-7; discussion 1077-8.

87. Glassford J, Eagle C, McMorland GH. Caesarean section in a patient with Cushing's syndrome. Can Anaesth Soc 1984;31:447-50.

88. Close CF, Mann MC, Watts JF, Taylor KG. ACTH-independent Cushing's syndrome in pregnancy with spontaneous resolution after delivery: control of the hypercortisolism with metyrapone. Clin Endocrinol (Oxf) 1993;39:375-9.

89. Berwaerts J, Verhelst J, Mahler C, Abs R. Cushing's syndrome in pregnancy treated by ketoconazole: case report and review of the literature. Gynecol Endocrinol 1999; 13:175-82.

90. Amado JA, Pesquera C, Gonzalez EM, Otero M, Freijanes J, Alvarez A. Successful treatment with ketoconazole of Cushing's syndrome in pregnancy. Postgrad Med J 1990; 66:221-3.

91. Prebtani AP, Donat D, Ezzat S. Worrisome striae in pregnancy. Lancet 2000;355:1692.

92. Khir AS, How J, Bewsher PD. Successful pregnancy after cyproheptadine treatment for Cushing's disease. Eur J Obstet Gynecol Reprod Biol 1982;13:343-7.

93. Hanson TJ, Ballonoff LB, Northcutt RC. Amino-glutethimide and pregnancy. JAMA 1974;230:963-4.

94. Leiba S, Weinstein R, Shindel B, Lapidot M, Stern E, Levavi H, et al. The protracted effect of o, $p^{\prime}-D D D$ in Cushing's disease and its impact on adrenal morphogenesis of young human embryo. Ann Endocrinol (Paris) 1989;50:49-53.

Address for correspondence:

Lucio Vilar

Rua Clovis Silveira Barros 84/1202

50050-270 Recife, PE

E-mail: Ivilar@gmail.com 